Ambiente \& Água - An Interdisciplinary Journal of Applied Science
ISSN 1980-993X - doi:10.4136/1980-993X
www.ambi-agua.net
E-mail: ambi.agua@gmail.com

\title{
Water balance for determination of excess water in soybean cultivated in lowland soils
}

ARTICLES doi:10.4136/ambi-agua.2614

Received: 01 Jul. 2020; Accepted: 25 Jan. 2021

\author{
Mateus Possebon Bortoluzzi ${ }^{*}$ (iD); Paulo Ivonir Gubiani2 ${ }^{\circledR}$; \\ Arno Bernardo Heldwein ${ }^{3}$; Roberto Trentin $^{4}{ }^{\circledR}$; Jocélia Rosa da Silva ${ }^{3}$; \\ Astor Henrique Nied ${ }^{3}$; ; Alencar Junior Zanon ${ }^{3}[$
}

\footnotetext{
${ }^{1}$ Faculdade de Agronomia e Medicina Veterinária. Universidade de Passo Fundo (UPF), Rodovia BR 285, km 292, CEP: 99052-900, Passo Fundo, RS, Brazil.

${ }^{2}$ Departamento de Solos. Universidade Federal de Santa Maria (UFSM), Avenida Roraima, ${ }^{\circ}$ 1000, CEP: 97105-900, Santa Maria, RS, Brazil. E-mail: paulogubiani@gmail.com

${ }^{3}$ Departamento de Fitotecnia. Universidade Federal de Santa Maria (UFSM), Avenida Roraima, ${ }^{\circ} 1000$, CEP: 97105-900, Santa Maria, RS, Brazil. E-mail: arno.heldwein@ufsm.br, jocelia.s@gmail.com, astor.nied@ufsm.br, alencarzanon@hotmail.com

${ }^{4}$ Departamento de Fitotecnia. Universidade Federal de Pelotas (UFPel), Campus Universitário Capão do Leão, s/n, CEP: 96010-610, Capão do Leão, RS, Brazil. E-mail: roberto.trentin@ufpel.edu.br

*Corresponding author. E-mail: mateusbortoluzzi@upf.br
}

\begin{abstract}
The aim of this study was to derive a methodology for calculating a sequential water balance that accurately estimates the occurrence of excess water in soybeans cultivated in lowlands. We tested four calculation strategies of water balance associated with the simulation of soybean development, which differed on the calculation of rainfall and time of water drainage from the soil macropores. Data of volumetric moisture monitored in three soil layers throughout the soybean cycle in the 2014/15 agricultural year were used as a reference. Microporosity was used as a lower limit for the occurrence of excess water in the area. Excess water was considered to be whenever the daily volumetric soil moisture in the 0-100 mm layer was greater than $0.39 \mathrm{~mm}^{3} \mathrm{~mm}^{-3}$. Over the 111 days of measurement, soil moisture indicated the presence of excess water in 38 days. The traditional calculation strategy of water balance underestimated the occurrence of excess water, as well as the other strategies that considered effective precipitation in their formulas. The calculation strategy that considers that all the rainfall infiltrates in the soil and that the water from macropores is removed only by crop evapotranspiration exhibited good performance and indicated 35 days of excess water, being the most appropriate and recommended for determining excess water in lowland soybeans.
\end{abstract}

Keywords: compute model, effective rainfall, Glycine max, hypoxia.

\section{Balanço hídrico para a determinação do excesso hídrico na soja em terras baixas}

\section{RESUMO}

O objetivo deste trabalho foi obter uma metodologia de cálculo do balanço hídrico sequencial que estime com acurácia a ocorrência de excesso hídrico na soja em terras baixas. Foram testadas quatro estratégias de cálculo do balanço hídrico associadas à simulação do 
desenvolvimento da soja, as quais se diferenciaram em função da forma de cômputo da chuva e do tempo de drenagem da água dos macroporos do solo. Como referência foram utilizados os dados de umidade volumétrica monitorada em três camadas de solo ao longo do ciclo da soja no ano agrícola 2014/15. A microporosidade foi utilizada como limite inferior da ocorrência de excesso hídrico na área. Assim, o excesso hídrico foi considerado sempre que a umidade volumétrica diária do solo na camada $0-100 \mathrm{~mm}$ foi maior que $0,39 \mathrm{~mm}^{3} \mathrm{~mm}^{-3}$. Ao longo dos 111 dias de medição, a umidade do solo indicou a presença de excesso hídrico em 38 dias. A estratégia de cálculo tradicional do balanço hídrico subestimou a ocorrência de excesso hídrico, assim como as demais estratégias que consideraram a precipitação efetiva na sua metodologia. A estratégia de cálculo que considera que toda a chuva infiltra no solo e que a água dos macroporos é removida somente pela evapotranspiração da cultura apresentou bom desempenho e indicou 35 dias de excesso hídrico, sendo a mais adequada e recomendada para a determinação do excesso hídrico na soja em terras baixas.

Palavras-chave: Glycine max, hipóxia, modelo de cômputo, precipitação efetiva.

\section{INTRODUCTION}

High demand for vegetable protein and favorable economic condition enables the expansion of soybean cultivation in areas that were not traditionally cultivated, i.e., the lowland areas in southern Brazil (Rocha et al., 2017; Sartori et al., 2016), entailing 1/3 of the area traditionally sown with irrigated rice (IRGA, 2019). In addition, crop rotation is an alternative to control weed infestations (Scherner et al., 2018; Fraga et al., 2019), break pest and disease cycles, improve soil conditions for plant development and increase the sustainability of the system (Goulart et al., 2020)

Imperfectly drained soils (Planosols) predominate in these areas due to the water table being close to the surface (Streck et al., 2008). In areas cultivated with irrigated rice, the superficial layers undergo disruption and compaction due to mechanized operations used for rice cultivation, which usually take place under soaked soil conditions and reduce the water infiltration rate (Sartori et al., 2016).

Excess water is one of the main risk factors for soybean grown in lowland areas (Bortoluzzi et al., 2017; Gubiani et al., 2018). The assessment of excess water can be performed by measuring the soil water content or aeration condition. However, prediction of risks due to excess water requires modeling the water balance throughout the crop cycle. Bortoluzzi et al. (2017) carried out a risk analysis of excess water for soybean cultivation in lowlands in the central region of Rio Grande do Sul (RS) by adapting the calculation of the daily sequential water balance (SWB) of Thornthwaite and Mather (1955). The authors also considered the effective precipitation (EP) of the U.S. Soil Conservation Service as infiltration as described by Frizzone and Andrade Júnior (2005) and applied the crop development model proposed by Trentin et al. (2013). Excess water was considered to be whenever the soil water content was above the field capacity. Another assumption was that after soil saturation two days of drainage were required for water content to decrease to field capacity.

One of the improvements required in the SWB carried out by Bortoluzzi et al. (2017) is the adjustment of the effective root depth. The authors considered that the roots explored a 0 $400 \mathrm{~mm}$ layer, based on the effective depth used in the SWB calculation performed by Fietz and Rangel (2008) for soybeans grown in well-drained soils (Latosol or Rhodic Hapludox). However, lowland studies have shown that soybean roots are concentrated in superficial layers, which requires redefinition of the layer utilized for the soil available water capacity (AWC) calculation. For example, there are reports that the taproot reached a maximum depth of 230 mm (Marchesan et al., 2013) and between $130 \mathrm{~mm}$ and $300 \mathrm{~mm}$ (Rocha et al., 2017). 
The deepening of roots is often restricted in lowland areas because the water table level is often close to the surface. Gubiani et al. (2018) found that soil moisture was close to the saturation moisture during practically the entire soybean crop cycle in the 300-400 mm layer. In this case, there is a strong impediment to root penetration, considering that soil saturation can cause the death of the soybean taproot and increase the growth of lateral and adventitious roots (Pires et al., 2002).

Flat relief hinders runoff and favors the accumulation of water on the lowland soil surface (Streck et al., 2008). Moreover, the use of effective precipitation (EP) from the U.S. Soil Conservation Service tends to underestimate infiltration and overestimate the runoff in these areas. Therefore, calculation adjustments for infiltration and runoff in the SWB carried out by Bortoluzzi et al. (2017) are also required to improve the model for predicting the risk of water excess for lowland soybeans.

Field capacity $\left(\theta_{\mathrm{fc}}\right)$ also deserves consideration to establish the upper limit of AWC. In soils with drainage limitations such as lowland soils, the concept of field capacity based on negligible drainage criteria is difficult to detect in the field. In addition, the time for soil water content to decrease to $\theta_{\text {fc }}$ in lowland soils is greater than in well-drained soils (Gubiani et al. 2018). This increased time can result in a significant portion of water available to plants while the water content in the soil is above $\theta_{\mathrm{fc}}$ (de Jong van Lier, 2017). In order to compute this additional available water, a strategy would be to replace $\theta_{\mathrm{fc}}$ with the $\theta$ corresponding to the microporosity in the AWC calculation, since the value of the second $(\theta$ at the $0.6 \mathrm{~m}$ pressure head) is slightly higher than the estimates of the first ( $\theta$ at the $1 \mathrm{~m}$ pressure head).

For lowland areas with slow drainage, a water balance calculation that immediately removes the water content from the soil between the upper AWC limit and soil saturation can underestimate the soil water content. If deep drainage from the macropores is very slow, the decrease in water content down to the AWC upper limit is predominantly dependent on the daily crop evapotranspiration. Furthermore, this adaptation can be included in SWB calculations to account for deep drainage limitations in lowland areas in determining excess water in soybeans.

Significant parts of the soybean process-based models were developed to estimate growth and productivity in the potential condition, without considering soil restrictions (Setiyono et al., 2010). Likewise, the CROPGRO model (Boote et al., 1998) allows the simulation of SWB and is one of the most used worldwide (Cera et al., 2017), but has weaknesses in the estimates of excess water simulations in lowlands (Fensterseifer et al., 2017).

This study aimed to explore whether the change in the parameterization of the upper limit of the AWC along with the inclusion of the calculation of macropore drainage time allows the SWB to better estimate the occurrence of excess water for lowland soybean cultivation.

\section{MATERIALS AND METHODS}

The study was carried out by comparing the excess water data obtained from four strategies of calculating the daily sequential water balance (SWB) with water excess data measured in a soybean field. The calculation and parameterization strategies, meteorological data and model calibration are described below.

TM1955: traditional methodology proposed by Thornthwaite and Mather (1955) and described by Pereira et al. (1997). In this strategy, the entire precipitation infiltrates in the soil, but only the amount of water held between an upper and a lower limit is considered for computing the AWC. Surplus water from precipitation is immediately drained and excess water is considered to be whenever the soil water storage exceeds the AWC upper limit.

The AWC calculation was performed by Equation 1: 
$A W C_{1}=\left(\theta_{m i c}-\theta_{p w p}\right) Z_{1}$

Where $\mathrm{AWC}_{1}$ is the available water capacity $(\mathrm{mm}), \theta_{\text {mic }}$ is the volumetric water content corresponding to the microporosity $\left(\mathrm{mm}^{3} \mathrm{~mm}^{-3}\right)$, which was set as the upper limit; $\theta_{\text {pwp }}$ is the volumetric water content at the permanent wilting point $\left(\mathrm{mm}^{3} \mathrm{~mm}^{-3}\right)$; and $\mathrm{Z} 1$ is the root system depth over the crop cycle $(\mathrm{mm})$.

Up to the first trifoliate leaf (V2), we considered $Z_{1}=100 \mathrm{~mm}$, which resulted in an $\mathrm{AWC}_{1}$ of $22 \mathrm{~mm}$. For the subperiod between V2 and the beginning of flowering (R1), the $\mathrm{AWC}_{1}$ ranged from $22 \mathrm{~mm}$ at $Z_{1}=100 \mathrm{~mm}$ to $66 \mathrm{~mm}$ at $Z_{1}=300 \mathrm{~mm}$. The deepening of the roots was simulated with a sigmoidal growth curve of the root system (Dourado Neto et al., 1999) as a function of the development rate (DR) calculated by a non-linear model of response to air temperature and photoperiod (Sinclair et al., 1991), according to Equation 2. The maximum depth of $300 \mathrm{~mm}$ was defined considering the root depth verified by Gubiani et al. (2018) in the study area. After R1, AWC 1 was maintained at $66 \mathrm{~mm}$. The $\theta_{\text {mic }}$ and $\theta_{\text {pwp }}$ values were, respectively, $0.39 \mathrm{~mm}^{3} \mathrm{~mm}^{-3}$ and $0.17 \mathrm{~mm}^{3} \mathrm{~mm}^{-3}$ (Gubiani et al., 2018).

$$
A W C_{n}=A W C_{V 2}+\frac{\left(A W C_{R 1}-A W C_{V 2}\right)}{2} \times[1-\cos \cos (\pi \times D R)]
$$

Where $\mathrm{AWC}_{\mathrm{n}}$ is the AWC stored in the day " $\mathrm{n}$ " $(\mathrm{mm}), \mathrm{AWC}_{\mathrm{V} 2}$ is the $\mathrm{AWC}$ stored up to V2 stage (mm), $A_{W} C_{R}$ is the AWC stored after R1 stage (mm); and DR is the development

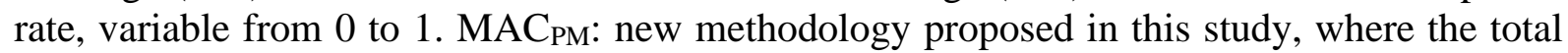
AWC was composed of a portion of the AWC stored in the micropores and another in the macropores (Figure 1). The AWC stored in the micropores is the $\mathrm{AWC}_{1}$ calculated in the $\mathrm{TM}_{1995}$ strategy.

The AWC stored in the macropores was calculated using Equation 3:

$$
A W C_{2}=\left(\theta_{\text {sat }}-\theta_{\text {mic }}\right) Z_{2}
$$

Where $\mathrm{AWC}_{2}$ is the AWC stored in the macropores $(\mathrm{mm}), \theta_{\text {sat }}$ is the volumetric water content at saturation $\left(\mathrm{mm}^{3} \mathrm{~mm}^{-3}\right)$; and $\mathrm{Z}_{2}$ is the root system depth up to which the effect of the water table level in the absence of flooding can be considered of little importance throughout the cycle $(\mathrm{mm}) . \mathrm{AWC}_{2}$ is computed only in a surficial layer (Figure 1) where the macropores will be occupied with water only in periods of complete saturation of the soil profile, generally coinciding with the flooding event. Based on the monitoring of $\theta$ by Gubiani et al. (2018) in the study area, $Z_{2}$ was considered $100 \mathrm{~mm}$ (Figure 1 ), and the $\theta_{\text {sat }}$ value was $0.45 \mathrm{~mm}^{3} \mathrm{~mm}^{-3}$.

The total AWC (AWC $\left.\mathrm{At}_{\text {to }}, \mathrm{mm}\right)$ was calculated using Equation (4):

$$
A W C_{\text {tot }}=A W C_{1}+A W C_{2}
$$

We also considered that all measured rainfall infiltrates the soil and that the maximum soil water storage is equal to $\mathrm{AWC}_{\text {tot. }}$. Excess water is considered to be whenever $\mathrm{AWC}>\mathrm{AWC}_{1}$, a condition that can occur due to excess precipitation and also due to the drainage time of the $\mathrm{AWC}$ portion occupying $\mathrm{AWC}_{2}$ after the end of the precipitation event. In situations where $\mathrm{AWC}_{1} \leq \mathrm{AWC} \leq \mathrm{AWC}_{\text {tot }}$ after the end of precipitation, the portion of $\mathrm{AWC}$ occupying $\mathrm{AWC}_{2}$ $\left(\mathrm{AWC}_{\text {tot }}-\mathrm{AWC}_{1}\right)$ is daily reduced by crop evapotranspiration. Consequently, there is a gradual reduction of water storage in the soil until reaching the upper limit of $\mathrm{AWC}_{1}$. The duration of this period depends on the condition of atmosphere evaporative demand and the crop development stage. During this period, the fraction of air-filled/water-filled macropores 
gradually increases and water excess due oxygen restriction gradually reduces. Usually, a value of $0.10 \mathrm{~mm}^{3} \mathrm{~mm}^{-3}$ of air-filled porosity is considered an empirical non-limiting threshold for aeration (Gubiani et al., 2018). We considered that the plants were subjected to oxygen deficiency while the soil macropores were not totally drained, because their capacity of store air $\left(\theta_{\text {sat }}-\theta_{\text {mic }}=0.06 \mathrm{~mm}^{-3} \mathrm{~mm}^{-3}\right)$ is less than the non-limiting threshold for aeration $\left(0.10 \mathrm{~mm}^{3}\right.$ $\left.\mathrm{mm}^{-3}\right)$.

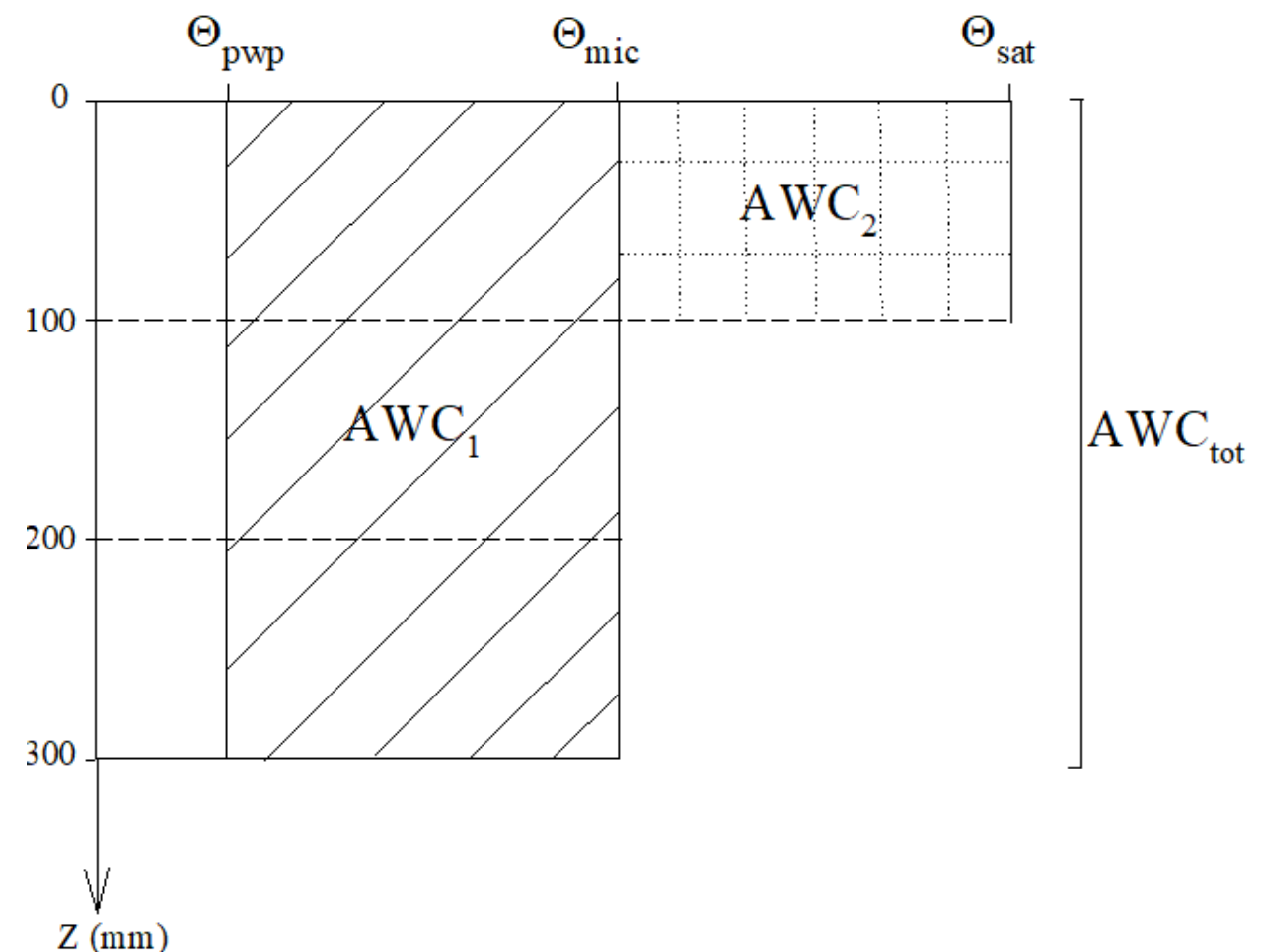

Figure 1. Scheme representation of the limits of soil water content referring to the methodologies that consider the drainage time of the macropores $\left(\mathrm{MAC}_{\mathrm{PM}}\right.$ and $\left.\mathrm{MAC}_{\mathrm{PE}}\right)$. They are represented by the soil water content between saturation $\left(\theta_{\text {sat }}\right)$ and microporosity $\left(\theta_{\text {mic }}\right)\left(\mathrm{AWC}_{2}\right)$ until $100 \mathrm{~mm}$ depth; $\mathrm{AWC}_{1}$ is the water content between $\theta_{\text {mic }}$ and permanent wilting point $\left(\theta_{\text {pwp }}\right)$ up to $300 \mathrm{~mm}$ depth $(\mathrm{Z})$ and $\mathrm{AWC}_{\text {tot }}$ is the sum of $\mathrm{AWC}_{2} \mathrm{e} \mathrm{AWC}_{1}$.

MAC $_{\mathrm{PE}}$ : this strategy is similar to $\mathrm{MAC}_{\mathrm{PM}}$, with the only difference being the consideration of the effective precipitation (EP) of the U.S. Soil Conservation Service as the water infiltrated into the soil, as described by Frizzone and Andrade Júnior (2005). The value of the curve number $(\mathrm{CN})$ used was 91 as the soil in the field area has more than half of the granulometric composition of silt and clay (Gubiani et al., 2018), and a loss of $25 \%$ of initial precipitation was assumed due to interception. Therefore, we were able to assess whether there is an important difference in the estimate of excess water due to the method of rain computation.

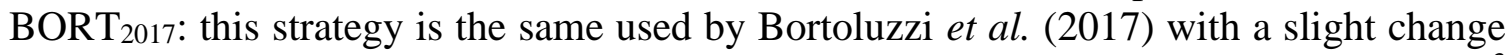
in the AWC upper limit, replacing the volumetric water content in the field capacity $\left(\theta_{\mathrm{fc}}, \mathrm{mm}^{3}\right.$ $\mathrm{mm}^{-3}$ ) by $\theta_{\text {mic }}$, which establishes the maximum water storage in the soil. Infiltration is considered to be EP (Frizzone and Andrade Júnior, 2005) and in the event of excess water from precipitation, a drainage time of two days is required for the soil to reach $\theta_{\text {mic }}$. Excess water is defined when water storage in the soil exceeds the AWC upper limit.

The four SWB calculation strategies use crop evapotranspiration (ETc) calculated as the product of reference evapotranspiration $\left(\mathrm{ET}_{\mathrm{o}}\right)$ by the crop coefficient $(\mathrm{Kc})$. $\mathrm{ET}_{\mathrm{o}}$ was estimated by means of the Penman-Monteith method (Allen et al., 1998). The FAO-recommended Kc values of $0.40,1.15$ and 0.50 for soybeans were considered constant respectively for the 
subperiods between sowing (S) and first trifoliolate leaf (V2); beginning of flowering (R1) to beginning of seed filling (R5) and from the beginning of maturation (R7) to full maturation (R8) (Allen et al., 1998). In the V2-R1 subperiod, the daily Kc was calculated respectively as a function of the variation in the relative development rate (SD) (Sinclair et al., 1991) and in the R5-R7 subperiod as a function of the thermal sum (Martorano et al., 2012), according to Equations 5 and 6:

$$
\begin{aligned}
& K c=1.087 \cdot S D+0.063 \\
& K c=-0.0012 \cdot T S_{R 5-R 7}+1.1512
\end{aligned}
$$

Where $\mathrm{Kc}$ is the crop coefficient, $\mathrm{SD}$ is the relative development rate and $\mathrm{TS}_{\mathrm{R} 5-\mathrm{R} 7}$ is the accumulated thermal sum between the R5- R7 subperiod.

All the daily meteorological data required to operationalize the four SWB calculation strategies were collected at the Main Weather Station of Santa Maria, RS, Brazil. The simulation period was from November 14, 2014 to March 26, 2015, which coincides with the period between soybean sowing and physiological maturity (Gubiani et al., 2018) in a lowland area at $800 \mathrm{~m}$ from the weather station. The daily water excess determined during the soybean cycle was used to evaluate the efficiency of the SWB calculation strategies.

The soybean was grown after a fallow season of a field previously cultivated with irrigated rice, with straw turnover after harvest. The field was leveled with a 'remaplan' blade and kept fallow during the winter season, with pre-emergent weed control. During the soybean crop, the volumetric water content in the soil $(\theta)$ was monitored with TDR100 sensors at 30 minute intervals in three soil layers from December 6, 2014 until the end of the cycle (111 days of monitoring). The calculation of excess water was performed through the $\theta$ daily mean measured at four monitoring points in the $0-100 \mathrm{~mm}$ depth layer, where most of the soybean roots were concentrated. Condition of excess water was considered whenever $\theta$ was greater than the volumetric water content corresponding to the microporosity $\left(\theta_{\text {mic }}\right)$ for this soil layer $\left(0.39 \mathrm{~mm}^{3}\right.$ $\mathrm{mm}^{-3}$ ).

Details of soybean cultivation, $\theta$ monitoring and microporosity determination are described in Gubiani et al. (2018). Lastly, the $\mathrm{TM}_{1955}$, MAC $\mathrm{PE}_{\mathrm{PE}}, \mathrm{MAC}_{\mathrm{PM}}$ and $\mathrm{BORT}_{2017}$ strategies were compared with each other and with the excess water measured in field conditions.

\section{RESULTS AND DISCUSSION}

The soil water content recorded by the TDR sensors in the $0-100 \mathrm{~mm}$ layer was greater than the microporosity $\left(\theta_{\text {mic }}=0.39 \mathrm{~mm}^{3} \mathrm{~mm}^{-3}\right)$ in 38 days of the 111 days of measurement period (Table 1). These 38 days of excess water (EXC) were due to the total rainfall of $551 \mathrm{~mm}$, distributed during the period from December 6, 2014 until March 26, 2015. The SWB modeling strategy that estimated the number of EXC days closest to the number of EXC days observed in the field (38 days) was MAC ${ }_{\mathrm{PM}}$, with 35 days of EXC (Table 1). Additional strategies were not very efficient, indicating respectively 17, 16 and 13 days of EXC with $\mathrm{MAC}_{\mathrm{PE}}, \mathrm{BORT}_{2017}$ and $\mathrm{TM}_{1955}$ (Table 1).

The $\mathrm{MAC}_{\mathrm{PE}}$ and $\mathrm{BORT}_{2017}$ strategies presented similar EXC days to field-observed values only until the beginning of January (Table 1). After that period, the strategies that used effective precipitation (EP) calculated by the U.S. Soil Conservation Service methodology as an estimate of soil water infiltration underestimated the number of days with EXC. However, Lucas et al. (2015) deployed a similar strategy to BORT 2017 , with satisfactory performance for sunflower cultivation in different types of highland soils, where the use of PE is more appropriate. 
Table 1. Measured daily volumetric soil moisture (Mv), measured precipitation (MP) and days with excess water (EXC) estimated by different water balance calculation strategies (*), over the soybean cycle in a Haplic Planosol during the 2014/15 agricultural year in Santa Maria, RS.

\begin{tabular}{|c|c|c|c|c|c|c|}
\hline Date & $M v^{*}\left(\mathrm{~mm}^{3} \mathrm{~mm}^{-3}\right)$ & $\mathrm{MP}(\mathrm{mm})$ & $\mathrm{MAC}_{\mathrm{PM}}$ & $\mathrm{MAC}_{\mathrm{PE}}$ & $\mathrm{BORT}_{2017}$ & $\mathrm{TM}_{1995}$ \\
\hline 09/12/2014 & - & 12.6 & EXC & - & & \\
\hline $10 / 12 / 2014$ & 0.427 & 22.6 & EXC & EXC & EXC & EXC \\
\hline $11 / 12 / 2014$ & 0.409 & 0 & EXC & EXC & EXC & - \\
\hline $12 / 12 / 2014$ & 0.395 & 0 & EXC & EXC & EXC & - \\
\hline $13 / 12 / 2014$ & - & 0 & EXC & EXC & - & - \\
\hline $16 / 12 / 2014$ & 0.401 & 0.5 & - & - & - & - \\
\hline $17 / 12 / 2014$ & 0.437 & 29.1 & EXC & EXC & EXC & EXC \\
\hline $18 / 12 / 2014$ & 0.429 & 0 & EXC & EXC & EXC & - \\
\hline $19 / 12 / 2014$ & 0.397 & 0 & - & - & EXC & - \\
\hline $21 / 12 / 2014$ & 0.438 & 71.6 & EXC & EXC & EXC & EXC \\
\hline $22 / 12 / 2014$ & 0.428 & 21.2 & EXC & EXC & EXC & EXC \\
\hline $23 / 12 / 2014$ & 0.403 & 0 & EXC & EXC & EXC & - \\
\hline $24 / 12 / 2014$ & - & 0 & - & - & EXC & - \\
\hline $27 / 12 / 2014$ & 0.433 & 101.1 & EXC & EXC & EXC & EXC \\
\hline $28 / 12 / 2014$ & 0.427 & 0.7 & EXC & EXC & EXC & - \\
\hline $29 / 12 / 2014$ & 0.430 & 3.5 & EXC & EXC & EXC & - \\
\hline $30 / 12 / 2014$ & 0.418 & 0 & EXC & - & - & - \\
\hline $31 / 12 / 2014$ & 0.405 & 0 & - & - & - & - \\
\hline $01 / 01 / 2015$ & 0.406 & 0 & - & - & - & - \\
\hline $02 / 01 / 2015$ & 0.444 & 23.8 & EXC & EXC & EXC & EXC \\
\hline 03/01/2015 & 0.427 & 0 & EXC & EXC & EXC & - \\
\hline $04 / 01 / 2015$ & 0.403 & 0 & - & - & EXC & - \\
\hline 09/01/2015 & 0.421 & 18.6 & - & - & - & - \\
\hline $10 / 01 / 2015$ & 0.432 & 14.7 & EXC & - & - & EXC \\
\hline $11 / 01 / 2015$ & 0.432 & 13 & EXC & EXC & - & EXC \\
\hline $12 / 01 / 2015$ & 0.429 & 0.1 & - & - & - & - \\
\hline $14 / 01 / 2015$ & 0.417 & 19.8 & EXC & EXC & - & EXC \\
\hline $15 / 01 / 2015$ & 0.441 & 8.8 & EXC & - & - & EXC \\
\hline $16 / 01 / 2015$ & 0.430 & 0 & EXC & - & - & - \\
\hline $17 / 01 / 2015$ & 0.436 & 10.5 & EXC & EXC & - & EXC \\
\hline $18 / 01 / 2015$ & 0.428 & 0 & EXC & - & - & - \\
\hline $29 / 01 / 2015$ & 0.448 & 33.8 & EXC & - & - & EXC \\
\hline $30 / 01 / 2015$ & 0.433 & 3.4 & EXC & - & - & - \\
\hline $31 / 01 / 2015$ & 0.394 & 0 & - & - & - & - \\
\hline $11 / 02 / 2015$ & 0.405 & 31.4 & - & - & & - \\
\hline $20 / 02 / 2015$ & 0.425 & 29.4 & - & - & - & - \\
\hline $21 / 02 / 2015$ & 0.395 & 0.1 & - & - & - & - \\
\hline $26 / 02 / 2015$ & 0.427 & 16.8 & EXC & - & - & - \\
\hline $27 / 02 / 2015$ & 0.416 & 4.6 & EXC & - & - & - \\
\hline $02 / 03 / 2015$ & 0.397 & 15.8 & EXC & - & - & EXC \\
\hline $03 / 03 / 2015$ & - & 0 & EXC & - & - & - \\
\hline $04 / 03 / 2015$ & - & 0 & EXC & - & - & - \\
\hline 05/03/2015 & 0.398 & 5.9 & EXC & - & - & - \\
\hline $06 / 03 / 2015$ & - & 0 & EXC & - & - & - \\
\hline $07 / 03 / 2015$ & - & 0 & EXC & - & - & - \\
\hline $11 / 03 / 2015$ & - & 9 & EXC & - & - & - \\
\hline $12 / 03 / 2015$ & - & 0 & EXC & - & - & - \\
\hline
\end{tabular}

(*) Soil moisture determined from data measured by Gubiani et al. (2018) in the 0-100 mm layer; (-) days without occurrence of water excess. $\mathrm{AWC}_{\mathrm{PM}}$ and $\mathrm{MAC}_{\mathrm{PE}}$ are strategies that respectively consider the measured precipitation (MP) and the effective precipitation (EP) as the time required to drain the macropores and use as infiltration; BORT $_{2017}$ is the methodology proposed by Bortoluzzi et al. (2017); $\mathrm{TM}_{1955}$ is the Thornthwaite and Mather (1955) methodology. 
In contrast, the $\mathrm{MAC} \mathrm{CP}_{\mathrm{PM}}$ strategy was efficient throughout the entire period because it considered that all precipitation infiltrates into the soil and that the water in the macropores is temporarily stored. The $\mathrm{TM}_{1955}$ strategy differs from $\mathrm{MAC}_{\mathrm{PM}}$ by not considering that water in the macropores is temporarily stored. Poor performance of $\mathrm{TM}_{1955}$ showed that water retention in the macropores is an important conditioning factor for EXC and should be included in WB models for accurate prediction of EXC.

The $\mathrm{TM}_{1955}$ strategy was able to indicate only one third of the days when there was water excess, evidencing considerable underestimation of EXC in lowlands. The low accuracy occurred because the $\mathrm{TM}_{1955}$ strategy does not consider that longer drainage time is necessary in lowlands (Mundstock et al., 2017). Mainly, whenever there was enough rain to saturate the soil, $\mathrm{TM}_{1955}$ was able to indicate the presence of excess water. However, when the rain stopped or if there was less rain than the crop evapotranspiration after the day of $\mathrm{EXC}$, the model removed water from the soil, making the current $\mathrm{AWC}$ less than $\mathrm{AWC}_{1}$ (Equation 1), which represents a condition without EXC. For instance, there was an accumulated rainfall of $111 \mathrm{~mm}$ on December 27, 2014, but the $\mathrm{TM}_{1955}$ strategy did not indicate EXC in the following day (Table 1). On the contrary, the $\mathrm{MAC}_{\mathrm{PM}}$ model indicated EXC in the following three days, precisely because it considers the delay in draining macropores (Table 1).

The $\mathrm{MAC}_{\mathrm{PM}}$ strategy indicated eight days of $\mathrm{EXC}$ without them having been detected by measurements of volumetric soil moisture (Table 1). However, this inconsistency occurred mainly at the end of the crop cycle, when this condition was verified six times. Until the end of February, the MAC ${ }_{P M}$ strategy indicated precisely the days when the water content measured by the TDR probe in the $0-100 \mathrm{~mm}$ layer was above the $\theta_{\text {mic }}\left(0.39 \mathrm{~mm}^{3} \mathrm{~mm}^{-3}\right)$ of that layer (Figure 2A). The lower accuracy of the $\mathrm{MAC}_{\mathrm{PM}}$ strategy at the end of the soybean cycle is due to the small crop evapotranspiration (mean of $2 \mathrm{~mm} \mathrm{day}^{-1}$ ), being insufficient to reduce $\mathrm{AWC}_{\text {tot }}$ up to the upper limit of $\mathrm{AWC}_{1}$. For example, the crop evapotranspiration of $2 \mathrm{~mm}^{-1 a y^{-1}}$ was insufficient for the total drainage of the macropores $\left(\mathrm{AWC}_{2}=0\right)$ from the $5^{\text {th }}$ to the $7^{\text {th }}$ of March, indicating the presence of EXC. Nevertheless, the volumetric water content of the $0-100 \mathrm{~mm}$ layer decreased from 0.39 to $0.32 \mathrm{~mm}^{3} \mathrm{~mm}^{-3}$ ( $7 \mathrm{~mm}$ of storage difference) in the same period (Figure 2A), characterizing the absence of EXC.

Measurements made with TDR showed that the water content in the 100-200 mm (Figure 2B) and 200-300 mm (Figure 2C) layers was also slightly less than the $\theta_{\text {mic }}$ of each layer at the end of the crop cycle. This indicates that there was participation of deep and/or lateral drainage in the extraction of water from the evaluated soil, but it was only relevant to affect the EXC estimates of the MAC ${ }_{\mathrm{PM}}$ strategy when there was low crop evapotranspiration.

Analyzing the concept of the MAC $\mathrm{PM}_{\mathrm{PM}}$ strategy, the likelihood of overestimating the EXC decreases with the increase in the ratio (crop evapotranspiration)/(deep and/or lateral drainage). Soybean crop evapotranspiration is lower in the initial and final growth stages, increasing the likelihood that deep and/or lateral drainage is not negligible for calculating EXC with the $\mathrm{MAC}_{\mathrm{PM}}$ strategy. However, these stages growth have less relative importance in reducing the productivity in comparison to the soybean vegetative and reproductive phases (Beutler et al.,

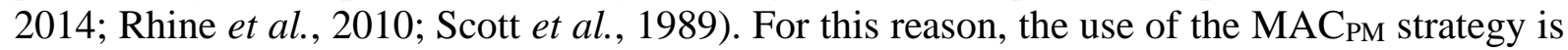
appropriate for soils where deep and/or lateral drainage can be considered negligible in relation to crop evapotranspiration.

The MAC $C_{P M}$ strategy was more efficient and accurate than the other strategies for predicting EXC in almost the entire soybean development cycle. The EXC indication was mostly consistent with the high volumetric water content in the soil measured in the field (Figure 2). In just 16 days in the 100-200 mm layer (Figure 2B) and 10 days in the 200-300 mm layer (Figure $2 \mathrm{C}$ ) the water content in the soil was below $\theta_{\text {mic. }}$ In this area, the water table was close to the surface for a considerable period due to the occurrence of high rainfall (Gubiani $e t$ $a l ., 2018)$. This demonstrates that the field scenario was of water excess and that the MAC $C_{P M}$ 
strategy was efficient in indicating the EXC on most days of its actual occurrence. Overall, the improvement of the excess water estimate through the SWB calculation contributes to the performance of risk analysis using historical series of meteorological data and future inclusion in soybean process-based models. Moreover, accurate estimates assist in the decision-making of management practices and in the reduction of the yield gap.
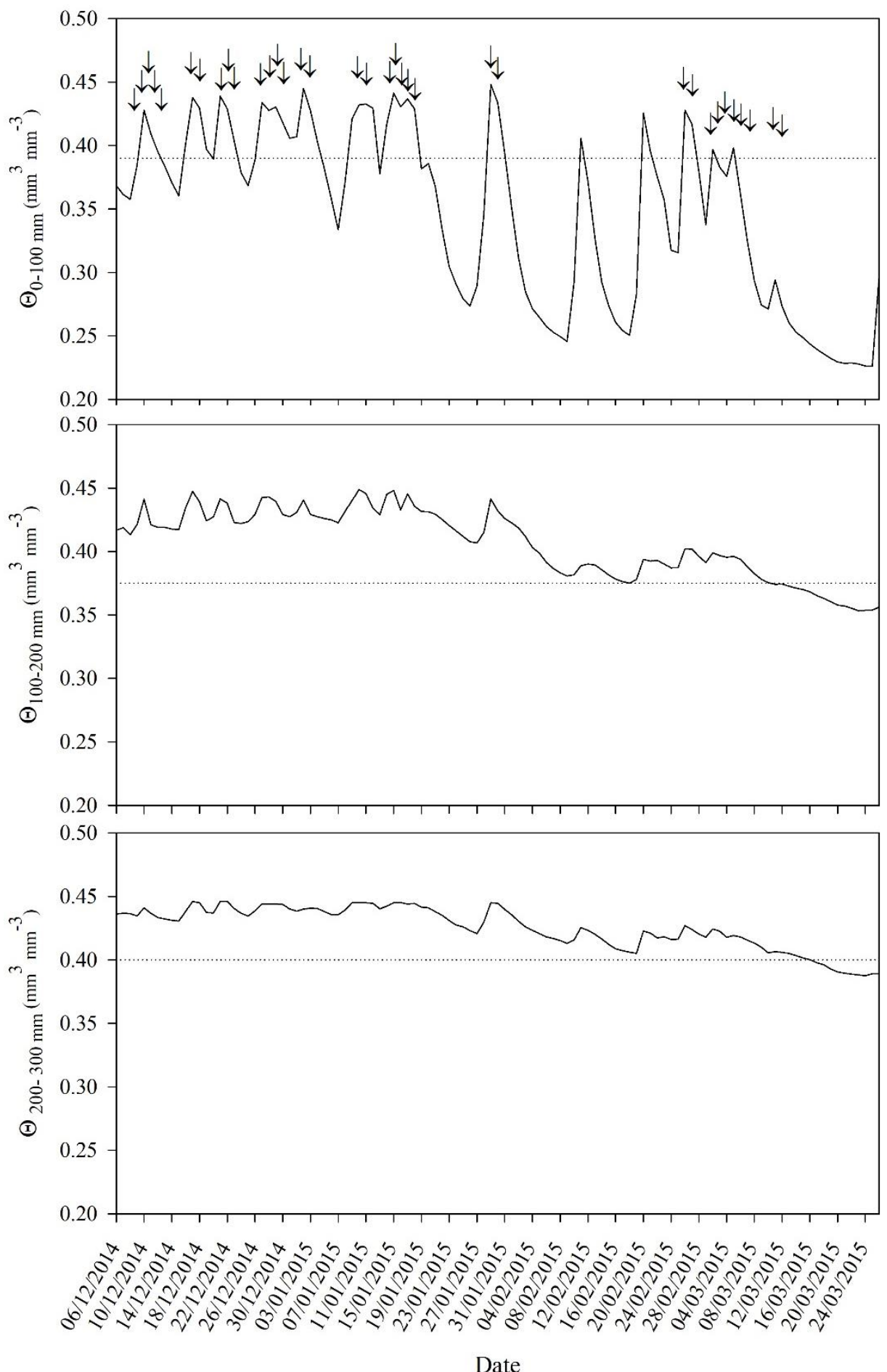

Figure 2. Volumetric water content in the soil $(\theta)$ throughout the soybean cycle in Planosol Haplic in the 0-100 mm (A), 100-200 mm (B) and 200-300 mm (C) layers. The horizontal dashed line represents the microporosity $\left(\theta_{\text {mic }}\right)$ and the arrows indicate the days of water excess obtained by the $\mathrm{MAC}_{\mathrm{PM}}$ methodology for calculating the sequential water balance. 


\section{CONCLUSIONS}

The traditional calculation strategy of water balance $\mathrm{TM}_{1955}$ underestimates the occurrence of water excess for lowland soybean cultivation.

The use of effective precipitation in water balance calculations also underestimates the occurrence of excess water in lowland field conditions.

The MAC ${ }_{\mathrm{PM}}$ calculation strategy considers that all precipitation infiltrates into the soil and delays the drainage time of the macropores; it is efficient and can be recommended for predicting excess water in soybeans cultivated in lowlands.

\section{ACKNOWLEDGEMENTS}

This work was performed with the financial support from the National Council for Scientific and Technological Development (CNPq) and the Coordination for the Improvement of Higher Education Personnel (CAPES).

\section{REFERENCES}

ALLEN, R. G. et al. Crop evapotranspiration-Guidelines for computing crop water requirements. Rome: Fao, 1998. (FAO Irrigation and drainage paper, 56).

BEUTlER, A. N.; GIACOMELI, R.; ALBERTO, C. M.; SILVA, V. N.; NETO, G. F. S.; MACHADO, G. A.; SANTO, A. T. L. Soil hydric excess and soybean yield and development in Brazil. Australian Journal of Crop Science. v. 8, n. 10, p. 1461-1466, 2014.

BOOTE, K. J.; JONES, J. W.; HOOGENBOOM, G. Simulation of crop growth: CROPGRO model. In: PEART, R. M.; CURRY, R. B. (Eds.). Agricultural Systems Modeling and Simulation. New York: Marcel Dekker, 1998. p. 651-692.

BORTOLUZZI, M. P.; HELDWEIN, A. B.; TRENTIN, R.; LUCAS, D. D. P.; RIGHI, E. Z.; LEONARDI, M. Risk of water surplus in soybean crop on haplic planosol soil in the Central Depression of Rio Grande do Sul State, Brazil. Ciência Rural, v. 47, n. 2, 2017. http://dx.doi.org/10.1590/0103-8478cr20160170

CERA, J. C.; STRECK, N. A.; YANG, H.; ZANON, A. J.; DE PAULA, G. M.; LAGO, I. Extending the evaluation of the SoySim model to soybean cultivars with high maturation groups. Field Crops Research, v. 201, p. 162-174, 2017. https://doi.org/10.1016/j.fcr.2016.11.006

DE JONG VAN LIER, Q. Field capacity, a valid upper limit of crop available water?

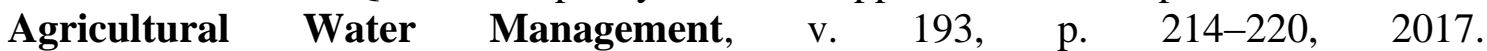
https://doi.org/10.1016/j.agwat.2017.08.017

DOURADO NETO, D.; GARCÍA, G. A.; FANCELLI, A. L.; FRIZZONE, J. A.; REICHARDT, K. Balance hídrico cíclico y secuencial: estimación de almacenamiento de agua en el suelo. Scientia Agrícola, v. 56, n. 3, p. 537-546, 1999. http://dx.doi.org/10.1590/S0103-90161999000300005

FENSTERSEIFER, C. A.; STRECK, N. A.; BAIGORRIA, G. A.; TIMILSINA, A. P.; ZANON, A. J.; CERA, J. C.; ROCHA, T. S.M. On the number of experiments required to calibrate a cultivar in a crop model: The case of CROPGRO-soybean. Field Crops Research. v. 204, p. 146-152, 2017. http://dx.doi.org/10.1016/j.fcr.2017.01.007 
FIETZ, C. R.; RANGEL, M. A. S. Época de semeadura da soja para a região de Dourados MS, com base na deficiência hídrica e no fotoperíodo. Engenharia Agrícola, v. 28, n. 4, p. 666-672, 2008. http://dx.doi.org/10.1590/S0100-69162008000400006

FRAGA, D. S.; AGOSTINETTO, D.; LANGARO, A. C.; OLIVEIRA, C.; ULGUIM, A. R.; SILVA, J. D. G. Morphological and Metabolic Changes in Soybean Plants Cultivated in Irrigated Rice Rotation and as Affected by Imazapyr and Imazapic Herbicides Carryover. Planta daninha, v. 37, 2019. http://dx.doi.org/10.1590/s0100-83582019370100023

FRIZZONE, J. A.; ANDRADE JÚNIOR, A. S. Planejamento de irrigação: Análise de decisão de investimentos. Brasília: Embrapa Informação Tecnológica, 2005. 627p.

GOULART, R. Z.; REICHERT, J. M.; RODRIGUES, M. F. Cropping poorly-drained lowland soils: alternative to rice monoculture, their challenges and management strategies. Agricultural Systems, v. 177, 2020. https://doi.org/10.1016/j.agsy.2019.102715

GUBIANI, P. I.; MÜLLER, E. A.; SOMAVILLA, A.; ZWIRTES, A. L.; MULAZZANI, R. P.; MARCHESAN, E. Transpiration reduction factor and soybean yield in lowland soil with ridge and chiseling. Revista Brasileira de Ciência do Solo, v. 42, p. 1-14, 2018. https://dx.doi.org/10.1590/18069657rbcs20170282

INSTITUTO RIOGRANDENSE DO ARROZ. Boletim de resultados da lavoura - safra 2018/19 - arroz irrigado e soja em rotação. 2019. Available at: https://irga.rs.gov.br/irgadivulga-boletim-de-resultados-da-safra-2018-2019. Access: 07 dez. 2019.

LUCAS, D. D. P.; HELDWEIN, A. B.; MALDANER, I. C.; TRENTIN, R.; HINNAH, F. D.; SILVA, J. R. Excedente hídrico em diferentes solos e épocas de semeadura do girassol no Rio Grande do Sul. Pesquisa Agropecuária Brasileira, v. 50, n. 6, p. 431-440, 2015. http://dx.doi.org/10.1590/S0100-204X2015000600001

MARCHESAN, E.; ARAMBURU, B. B.; VIZZOTTO, V. R.; OLIVEIRA, M. L.; CASTRO, I. A.; TONETTO, F.; GIACOMELI, R. Sistema de implantação e seus efeitos na resistência mecânica do solo à penetração de raízes e na produtividade de soja em área de várzea. In: CONGRESSO BRASILEIRO DE ARROZ IRRIGADO, 8., 12-15 de agosto 2013, Santa Maria. Anais[...]. Santa Maria: Epagri, 2013. v. 2. p. 120-123. Available at: http://cbai2013.web2265.uni5.net/cdonline/docs/trab-5979-535.pdf. Access: 15 jan. 2020.

MARTORANO, L. G.; BERGAMASCHI, H.; FARIA, R. T.; DALMAGO, G. D. Decision Strategies for Soil Water Estimations in Soybean Crops Subjected to No-Tillage and Conventional Systems, in Brazil. In: KUMAR, M. (Org.). Problems, Perspectives and Challenges of Agricultural Water Management. Rijeka: InTech, 2012, p. 439-453.

MUNDSTOCK, C. M.; SCHOENFELD, R.; ALMEIDA, D.; UHRY JUNIOR, D. F. ; CARLOS, F. S.; ZANON, A. J.; ULGUIM, A. R.; OGOSHI, C.; MARCOLIN, E.; MORAES, F. A.; BADINELLI, P. G.; SILVA, P. R. F.; ANGHINONI, I. Soja 6.000 Manejo para alta produtividade em terras Baixas. 1. ed. Porto Alegre: IRGA, 2017. $68 \mathrm{p}$.

PEREIRA, A. R.; VILLA NOVA, N. A.; SEDIYAMA, G. C. Evapo(transpi)ração. Piracicaba: FEALQ, 1997. 183p.

PIRES, J. L. F.; SOPRANO, E.; CASSOL, B. Adaptações morfofisiológicas da soja em solo inundado. Pesquisa Agropecuária Brasileira, v. 37, n. 1, p. 41-50, 2002. http://dx.doi.org/10.1590/S0100-204X2002000100006 
RHINE, M. D.; STEVENS, G.; SHANNON, G.; WRATHER, A.; SLEPER, D. Yield and nutritional responses to waterlogging of soybean cultivars. Irrigation Science, v. 28, n. 2, p.135-142, 2010.http://dx.doi.org/10.1007/s00271-009-0168-x

ROCHA, T. S. M.; STRECK, N. A.; ZANON, A. J.; PETRY, M. T.; TAGLIAPIETRA, E. L.; BALEST, D.; BEXAIRA, K. P.; MARCOLIN, E. Performance of soybean in hydromorphic and non hydromorphic soil under irrigated or rainfed conditions. Pesquisa Agropecuaria Brasileira, v. 52, n. 5, p. 293-302, 2017.https://doi.org/10.1590/s0100$204 \times 2017000500002$

SARTORI, G. M. S.; MARCHESAN, E.; DAVID, R.; DONATO, G.; COELHO, L. L.; AIRES, N. P.; ARAMBURU, B. B. Soil tillage systems and seeding on grain yield of soybean in lowland area. Ciência Rural, v. 46, n. 3, p. 492-498, 2016. http://dx.doi.org/10.1590/0103-8478cr20150676

SCOTT, H. D.; DEANGULO, J.; DANIELS, M. B.; WOOD, L. S. Flood duration effects on soybean growth and yield. Agronomy Journal, v. 81, n. 4, p. 631-636, 1989. http://dx.doi.org/10.2134/agronj1989.00021962008100040016x

SCHERNER, A.; SCHREIBER, F.; ANDRES, A.; CONCENÇO, G.; MARTINS, M. B.; PITOL, A. Rice crop rotation: a solution for weed management. In: SHAH, F.; KHAN, Z. H.; IQBAL, A. (eds.). Rice crop t current developments. London: IntechOpen, 2018. https://dx.doi.org/10.5772/intechopen.75884

SETIYONO, T. D.; CASSMAN, K. G.; SPECHT, J. E.; DOBERMANN, A.; WEISS, A.; YANG, H.; CONLEY, S. P.; ROBINSON, A. P.; PEDERSEN, P.; DE BRUIN, J. L. Simulation of soybean growth and yield in near-optimal growth conditions. Field Crops Research, v. 119, p. 161-174, 2010. http://dx.doi.org/10.1016/j.fcr.2010.07.007

SINCLAIR, T. R.; KITANI, S.; KITANI, S.; HINSON, K.; BRUNIARD, J.; HORIE, T. Soybean flowering date: linear and logistic models based on temperature and photoperiod. Crop Science, v. 31, n. 3, p. 786-790, 1991. http://dx.doi.org/10.2135/cropsci1991.0011183X003100030049x

STRECK, E. V. et al. Solos do Rio Grande do Sul. 2. ed. Porto Alegre: EMATER/RSASCAR, 2008. 222 p.

THORNTHWAITE, C. W.; MATHER, J. R. The water balance. Centerton: Drexel institute of technology, 1955. (Publications in Climatology).

TRENTIN, R.; HELDWEIN, A. B.; STRECK, N. A.; TRENTIN, G.; SILVA, J. C. Subperíodos fenológicos e ciclo da soja conforme grupos de maturidade e datas de semeadura. Pesquisa Agropecuária Brasileira, v. 48, n. 7, p. 703-713, 2013. http://dx.doi.org/10.1590/S0100-204X2013000700002 